\title{
PERBEDAAN ASUPAN MAKANAN PADA AKHIR PUASA RAMADHAN DENGAN SATU MINGGU, DUA MINGGU DAN TIGA MINGGU SETELAH IDUL FITRI PADA KOMPI VI TANK BANDUNG
}

\author{
Lola Ilona ${ }^{1}$, Setiawan², Gaga Irawan Nugraha ${ }^{2}$, Titing Nurhayati ${ }^{2}$ \\ ${ }^{1}$ Program Studi Ilmu Kedokteran Dasar, Fakultas Kedokteran, Universitas Padjadjaran \\ ${ }^{2}$ Departemen Anatomi Fisiologi dan Biologi Sel, Fakultas Kedokteran, Universitas Padjadjaran
}

\begin{abstract}
Indonesia Muslim society is obligated to carry out the fast of Ramadan. In general the Muslims carring out fasting Ramadan is likely to consume foods that are high in fat, protein and karbohoidrat although the frequency and amount of eating food intake decreases. The habit of eating foods wide high in fat, protein and karbohoidrat maintained until after the Eid al-Fitr. This research aims to know the differences in energy intake comes from carbohydrates, protein and fat between the end of the Ramadan fasting (25/9/2008) and the time of Eid al-Fitr, 1 week (6/10/2008), 1 week (15/10/2008), 1 week (24/10/2008) after the Eid al-Fitr.The subject is a member company of Yonkav (cavalry battalion) 4 Tanks of Bandung, randomly selected, aged 2029 years, already carry out month-long fast of Ramadan and in a healthy condition. Type of this research is a descriptive longtudinal. Food intake at the end of the fast of Ramadan (25/9/2008), 1 week (6/10/2008), 1 week (15/10/2008), 1 week (24/10/2008) after the Eid al-Fitr is recorded using the 24-hour recall. The data obtained are then processed to obtain data regarding the percentage of total energy intake, the intake of energy comes from carbohydrates, proteins and fats. The results showed a rise in total energy intake and energy intake comes from fat also decrease intake of energy comes from carbohydrates on Idul Fitri, 1 week, 2 weeks, 3 weeks after Idul Fitri as compared to the end of the fasting of Ramadan. While the intake of energy derived from protein, has no change.
\end{abstract}

Key words: food intake, fasting Ramadan, fasting 


\section{PENDAHULUAN}

Negara Indonesia mayoritas penduduknya beragama Islam. Masyarakat Indonesia yang beragama Islam wajib melaksanakan shaum Ramadan atau disebut juga 'puasa Ramadan'. Puasa di bulan Ramadan ini dilaksanakan setahun sekali dan diakhiri dengan perayaan Idul Fitri pada awal bulan Syawal, sehingga bagi kebanyakan kaum muslimin, ibadah ini merupakan momen yang istimewa. Kata shaum berasal dari bahasa 'Arab yang artinya menahan. Setiap orang yang melaksanakan 'ibadah puasa diperintahkan untuk menahan diri dari makan dan minumsejak fajar menyingsing sampai matahari terbenam. Rata-rata pelaksanaan puasa per hari di Indonesia kurang lebih selama 14 jam. Pada saat melaksanakan ibadah puasa di bulan Ramadan terdapat perubahan asupan makanan.

Pada umumnya umat Islam yang melaksanakan puasa Ramadan cenderung untuk mengkonsumsi makanan manis atau tinggi karbohoidrat. Selain mengkonsumsi makanan tinggi karbohidrat, pada saat bulan puasa, menurut Gharbi, 2003 terdapat pula kecenderungan mengkonsumsi makanan tinggi lemak dan tinggi protein meskipun frekuensi makan dan jumlah asupan makanan menurun (Gharbi, Akrout, dan Zouari, 2003). Kecenderungan mengkonsumsi makanan tinggi karbohidrat, protein dan lemak selama bulan puasa akan dipertahankan hingga sesudah Idul Fitri (AlHourani dan Atoum, 2007). Akan tetapi para ahli lain mengatakan bahwa setelah Idul Fitri dapat pula terjadi perubahan pola makan yang berbeda dengan pola makan yang dijalankan selama bulan Ramadan (Beltaifa, 2002). Apabila sesudah bulan puasa kecenderungan asupan makanan dengan tinggi karbohidrat, protein dan lemak tetap dipertahankan maka akan mempengaruhi indeks massa tubuh dan komposisi tubuh.

Menurut Hoffer, 2006 pada seseorang yang melaksanakan pola makan semi-starvasi antara lain sepert melaksanakan ibadah puasa akan terjadi penurunan Basal Metabolic Rate (BMR) yang disebabkan oleh rendahnya kadar T3 dan T4 serta berkurangnya massa otot, selain itu, terjadi pula penurunan termogenesis pada massa otot. Penurunan BMR dan termogenesis pada massa otot akan menyebabkan menurunnya Total Energy Expenditure (TEE). Oleh karena terdapat kecenderungan asupan tinggi karbohidrat, protein dan lemak pada bulan puasa, maka kelebihan energi tersebut akan disimpan sebagai trigliserida dalam jaringan adiposa (Kurpad, 2005; Hoffer, 2006). Adanya perbedaan pola asupan makanan selama bulan puasa dengan sesudah bulan puasa kemungkinan berpengaruh terhadap komposisi tubuh. Hal ini diperkuat pula oleh Dullo bahwa pada saat pemulihan berat badan pasca starvasi, massa lemak lebih cepat kembali ke kondisi semula dibandingkan dengan massa bebas lemak (Dulloo, Jacquet, dan Montani, 2002). Selain adanya perubahan yang disebutkan di atas terjadi pula perubahan hormonal selama bulan puasa, yaitu: kadar insulin darah, glukagon, katekolamin, leptin yang secara keseluruhan akan menyebabkan penurunan massa lemak dan massa bebas lemak. Pada keadaan semi-starvasi didapatkan persentase penurunan massa lemak yang lebih banyak dibandingkan dengan penurunan massa bebas lemak (Dullo dan Girardier, 1993; Dullo dkk., 1995; Dullo, Jacquet, dan Girardier, 1996; Hall, 2006).

Adanya perubahan pola asupan makanan selama bulan puasa dengan sesudah bulan puasa dapat diukur melalui recall 24 jam untuk mengetahui pola asupan makanan

Menurut Lamine, 2006 Pengukuran perubahan asupan makanan dilakukan selama semistarvasi dan 3 minggu setelah semi-starvasi sudah pernah dilakukan, akan tetapi pengukuran profil asupan makanan setelah puasa, 1 minggu setelah puasa, 2 minggu setelah puasa, 3 minggu setelah puasa, belum ada penelitiannya sampai saat ini. Pengukuran ini diperlukan untuk mengetahui kurva perubahan asupan makan pasca Ramadan (Lamine dkk., 2006).

Tujuan penelitian ini adalah untuk mengetahui perbedaan asupan energi yang berasal dari karbohidrat, protein dan lemek antara akhir puasa Ramadan dengan saat Idul Fitri, 1 minggu, 2 minggu, 3 minggu setelah Idul Fitri pada anggota Kompi Yonkav 4 Tank.

\section{METODE}

Subjek penelitian adalah anggota kompi Yonkav (batalyon kavaleri) 4 Tank Bandung yang dipilih secara acak, berusia 20-29 tahun, sudah melaksanakan puasa Ramadan sebulan penuh dan dalam kondisi sehat.

\section{Bentuk dan Rancangan Penelitian}

Tipe penelitian ini adalah deskriptif longtudinal dalam bidang ilmu gizi klinik.

\section{Prosedur Penelitian}

Penelitian ini melibatkan anggota Kompi Yonkav 4 Tank Bandung yang telah menjalani puasa Ramadan bulan September 2008. Pada akhir bulan Ramadan (24 September 2008), 1 minggu (6 Oktober 2008), 2 minggu (14 Oktober 2008) 3 minggu (24 Oktober 2008) dilakukan pencatatan asupan makanan dengan menggunakan recall 24 jam. Untuk asupan makanan pada hari raya Idul Fitri dilakukan food record yang dikonfirmasi dengan 
wawancara pada 1 minggu setelah Idul Fitri. Data yang diperoleh kemudian diolah dengan menggunakan program Nutrisurvey 2005 untuk memperoleh data mengenai asupan energi total, persentase asupan energi yang berasal dari karbohidrat, protein dan lemak.

\section{Pengolahan dan Analisis Data}

Data mengenai asupan energi total, asupan karbohidrat, asupan protein dan asupan lemak kemudian diolah dengan menggunakan program "SPSS for Windows versi 13" dan "Microsoft Excel 2007" untuk mengetahui perubahan asupan makanan pada saat Idul Fitri, 1 minggu, 2 minggu, 3 minggu setelah Idul Fitri.

\section{HASIL}

Data hasil pengukuran asupan energi total, persentase asupan energi yang berasal dari karbohidrat, protein dan lemak pada saat akhir puasa Ramadan, hari raya Idul Fitri, 1 minggu, 2 minggu dan 3 minggu setelah Idul Fitri pada kompi Yonkav 4 Tank tercantum pada tabel 1 .

Tabel 1 menunjukan bahwa data asupan energi (kkal), asupan karbohidrat, asupan protein dan asupan lemak pada saat akhir puasa Ramadan, hari raya Idul Fitri, 1 minggu, 2 minggu dan 3 minggu setelah Idul Fitri pada kompi Yonkav 4 Tank berdistribusi normal kecuali asupan energi (kkal) pada akhir puasa Ramadan, asupan protein (\%) pada akhir puasa Ramadan, asupan energi (kkal) pada hari raya Idul Fitri.

Untuk menilai perbedaan secara keseluruhan data asupan energi (kkal), persentase asupan energi yang berasal dari karbohidrat, protein dan lemak saat akhir puasa Ramadan, hari raya Idul Fitri, 1 minggu, 2 minggu, 3 minggu setelah Idul Fitri pada Kompi Yonkav 4 Tankdilakukan uji Friedman $(p<0,05)$. Selanjutnya, untuk mengetahui perbedaan asupan energi (kkal), persentase asupan energi yang berasal dari karbohidrat, protein dan lemak antara akhir puasa Ramadan dengan hari raya Idul Fitri, 1 minggu, 2 minggu, 3 minggu setelah hari raya Idul Fitri, dilakukan uji Wilcoxon $(\mathrm{p}<0,05)$.

Untuk menilai perbedaan data asupan energi (kkal) secara keseluruhan pada akhir puasa Ramadan, hari raya Idul Fitri, 1 minggu, 2 minggu, 3 minggu setelah hari raya Idul Fitri menggunakan uji non parametrik Friedman dengan kemaknaan $\mathrm{p}=$ $0,000(\mathrm{p}<0,05)$.

Tabel 1 Asupan Energi Total, Persentase Asupan Energi yang berasal dari Karbohidrat, Proteindan Lemak pada Akhir Puasa Ramadan, Hari Raya Idul Fitri, 1 minggu, 2 minggu, 3 minggu setelah Idul Fitri pada Kompi Yonkav 4 Tank

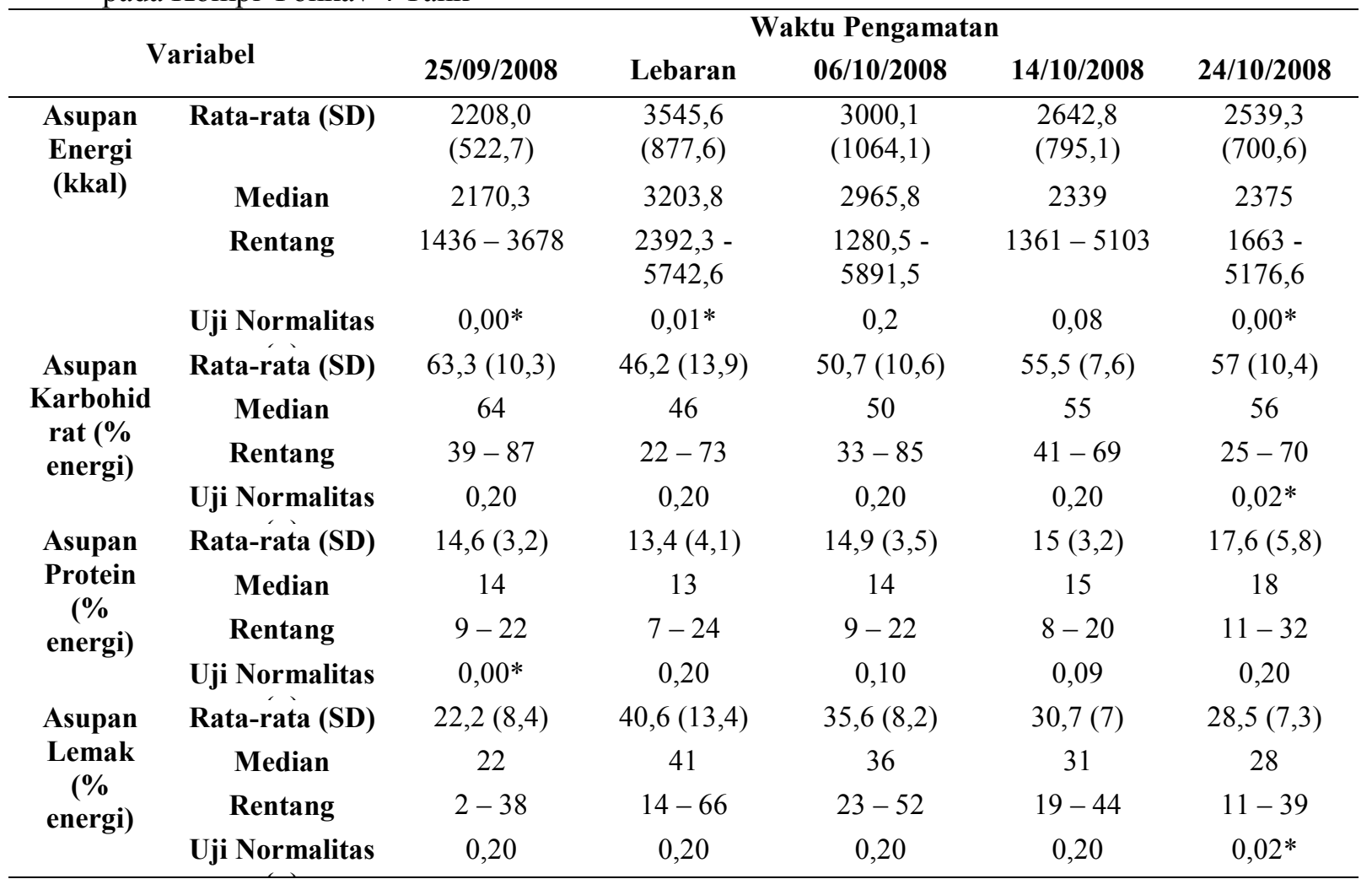

Keterangan : Uji normalitas menggunakan uji Kolmogorov-Smirnov dengan kemaknaan $\mathrm{p}<0,05$

* menunjukan data tidak berdistribusi normal 


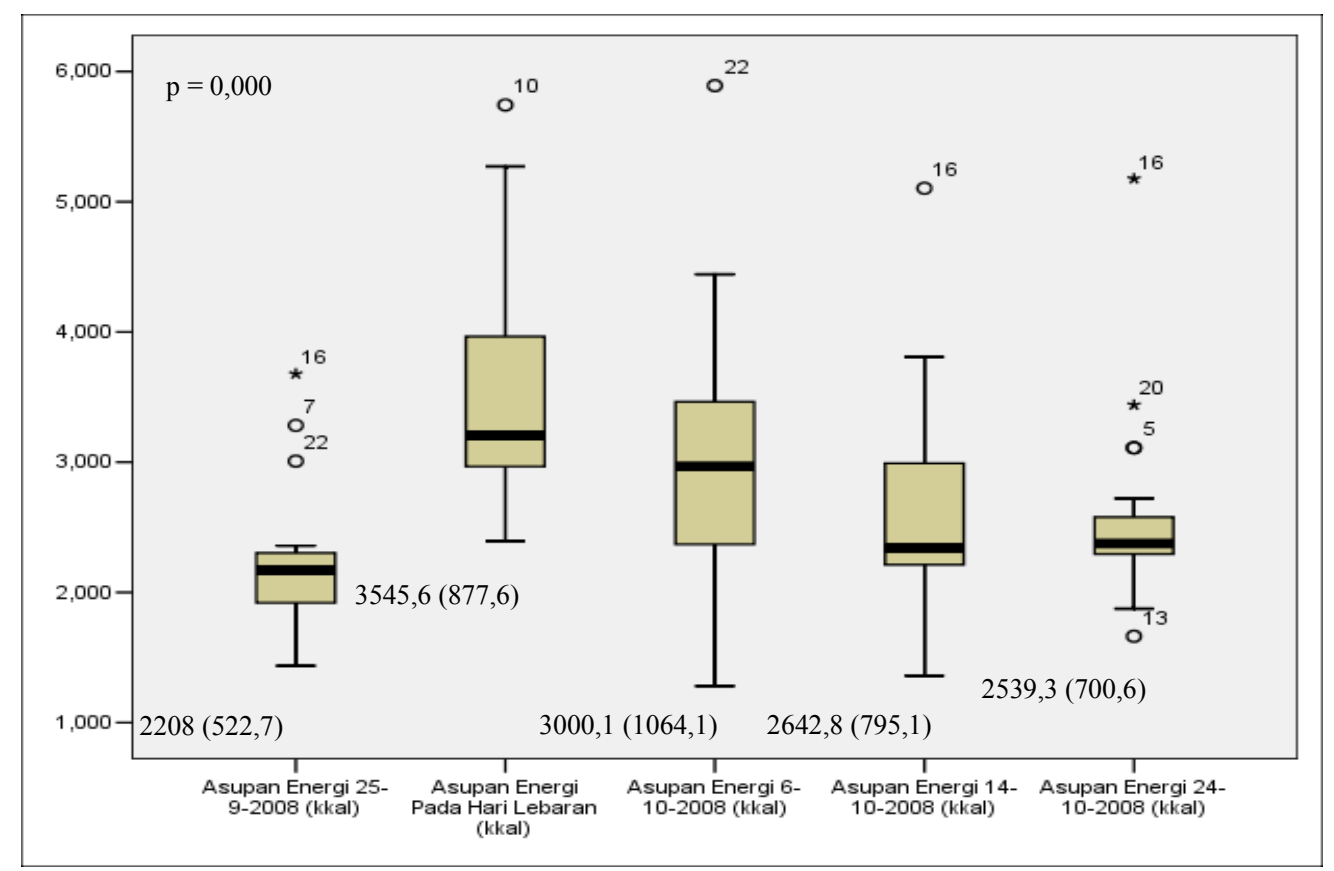

Gambar 1 Grafik Asupan Energi (kkal) pada Akhir Puasa Ramadan 25/9/2008), Hari Raya Idul Fitri, 1 minggu (6/10/2008), 2 minggu (14/10/2008), 3 minggu 24/10/2008) setelah Idul Fitri pada Kompi Yonkav 4 Tank

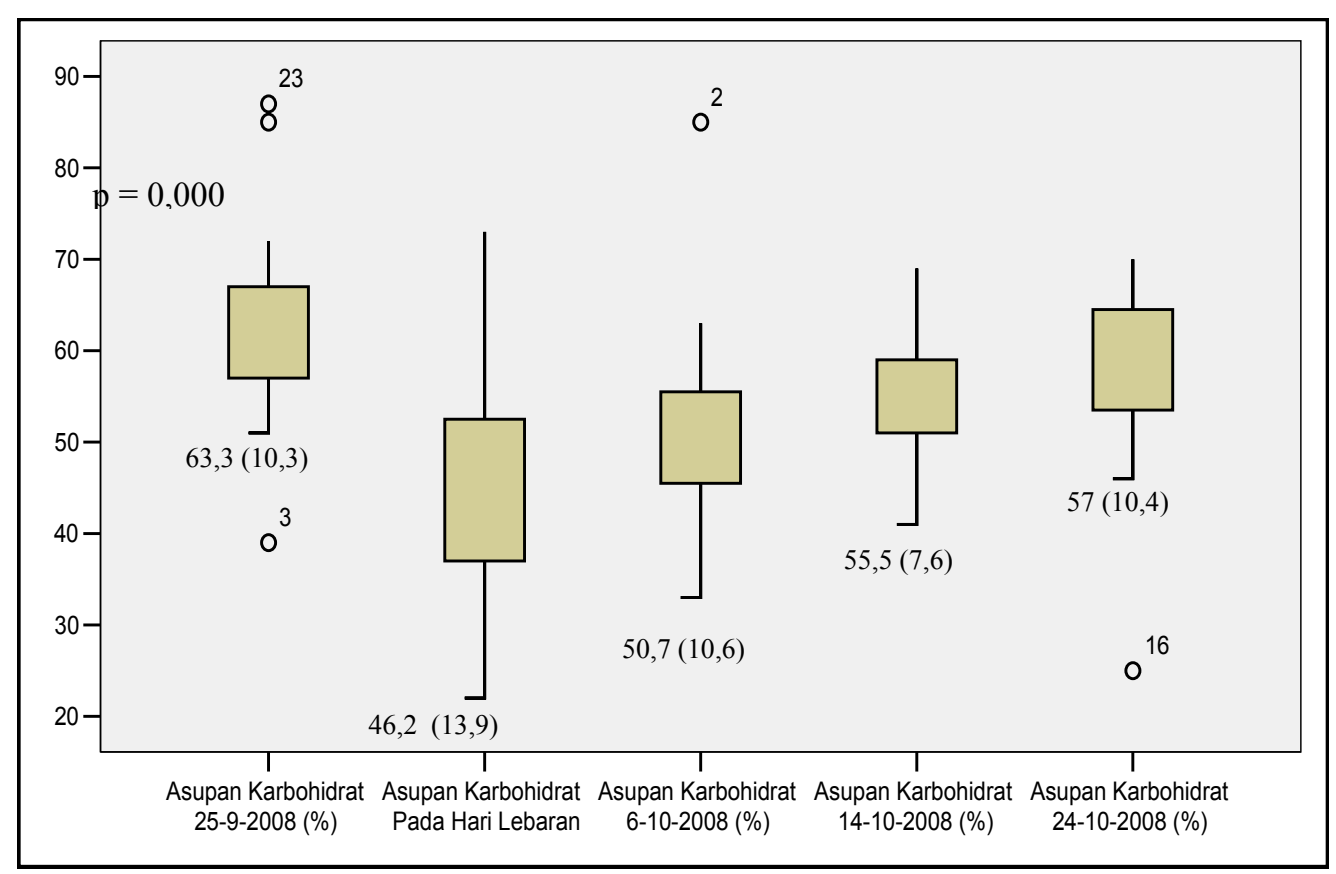

Gambar 2 Persentase Asupan Energi yang berasal dari Karbohidrat pada Akhir Puasa Ramadan (25/9/2008), Hari Raya Idul Fitri, 1 minggu (6/10/2008), 2 minggu (14/10/2008), 3 minggu (24/10/2008) setelah Idul Fitri pada Kompi Yonkav 4 Tank 
Tabel 3 Perbedaan Asupan Karbohidrat (\%) antara Akhir Puasa Ramadan dengan Hari Raya Idul Fitri, 1 minggu, 2 minggu, 3 minggu setelah Idul Fitri pada Kompi Yonkav 4 Tank

\begin{tabular}{ccc}
\hline$\Delta$ Asupan karbohidrat (\%) & Rata-rata (SD) & $\mathbf{p}$ \\
\hline $\mathbf{0}-\mathbf{1}$ & $-25,1(25)$ & 0,000 \\
$\mathbf{0}-\mathbf{2}$ & $-17,9(22,7)$ & 0,001 \\
$\mathbf{0}-\mathbf{3}$ & $-10,6(16,1)$ & 0,002 \\
$\mathbf{0}-\mathbf{4}$ & $-7,8(21,7)$ & 0,038 \\
\hline
\end{tabular}

\section{Keterangan:}

$0=$ akhir puasa Ramadan

$1=$ hari raya Idul Fitri

$2=1$ minggu setelah hari raya Idul Fitri

$3=2$ minggu setelah hari raya Idul Fitri

$4=3$ minggu setelah hari raya Idul Fitri

$\Delta=\left(\left(\mathrm{X}_{1}-\mathrm{X}_{0}\right) / \mathrm{X}_{0}\right) * 100 \%$

$\mathrm{p}$ menggunakan uji non parametrik Wilcoxon $\mathrm{p}=0,06$

Tabel 4 Perbedaan Asupan Lemak (\%) antara Akhir Puasa Ramadan dengan Hari Raya Idul Fitri, 1 minggu, 2 minggu, 3 minggu setelah Idul Fitri pada Kompi Yonkav 4 Tank

\begin{tabular}{ccc}
\hline$\Delta$ Asupan Lemak (\%) & Rata-rata (SD) & p \\
\hline $\mathbf{0}-\mathbf{1}$ & $211,3(521,6)$ & 0,000 \\
$\mathbf{0}-\mathbf{2}$ & $132,7(254,3)$ & 0,000 \\
$\mathbf{0}-\mathbf{3}$ & $121,9(320)$ & 0,002 \\
$\mathbf{0}-\mathbf{4}$ & $72,6(153,7)$ & 0,006 \\
\hline
\end{tabular}

\section{Keterangan}

$0=$ akhir puasa Ramadan

$1=$ hari raya Idul Fitri

$2=1$ minggu setelah hari raya Idul Fitri

$3=2$ minggu setelah hari raya Idul Fitri

$4=3$ minggu setelah hari raya Idul Fitri

$\Delta=\left(\left(\mathrm{X}_{1}-\mathrm{X}_{0}\right) / \mathrm{X}_{0}\right) * 100 \%$

$\mathrm{p}$ menggunakan uji non parametrik Wilcoxon $\mathrm{p}=0,000$

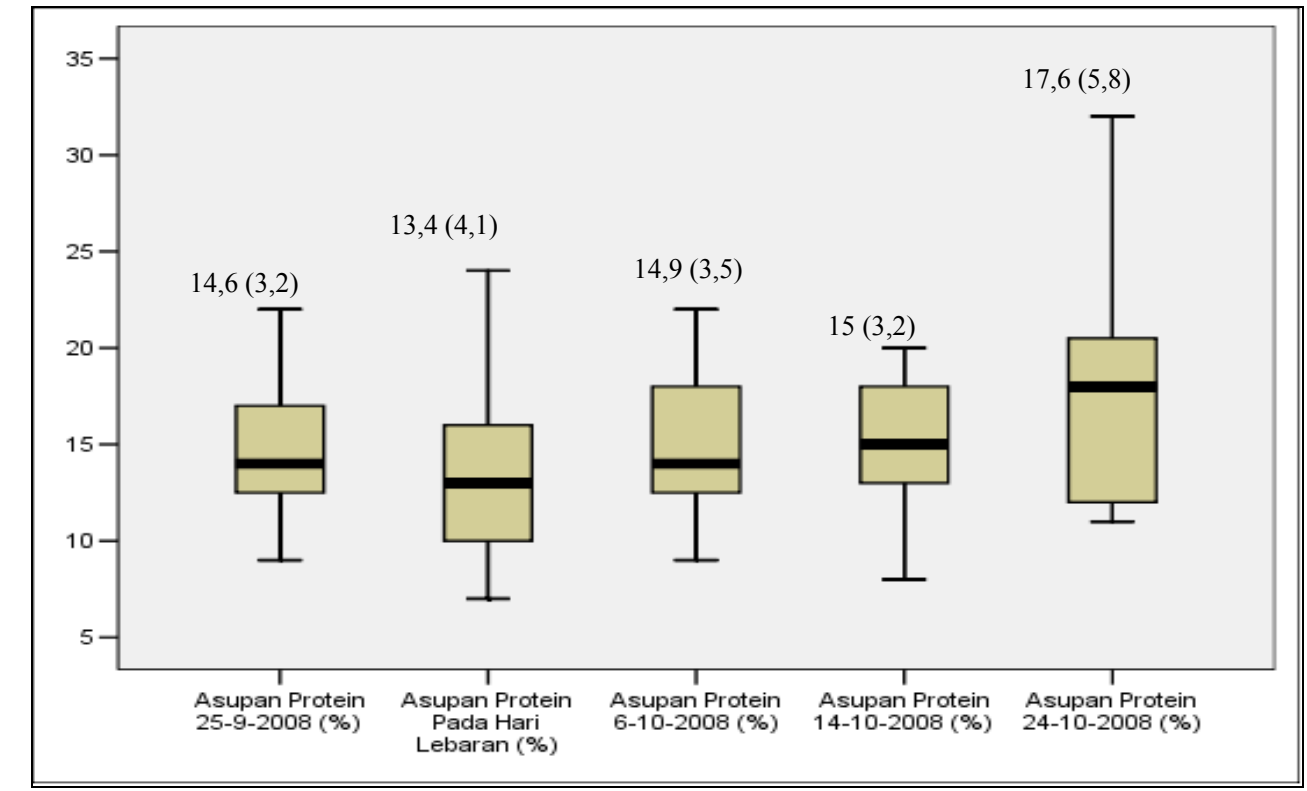

Gambar 3 Persentase Asupan Energi yang berasal dari Protein pada Akhir Puasa Ramadan (25/9/2008), Hari Raya Idul Fitri, 1 minggu (6/10/2008), 2 minggu (14/10/2008), 3 minggu (24/10/2008) setelah Idul Fitri pada Kompi Yonkav 4 Tank 


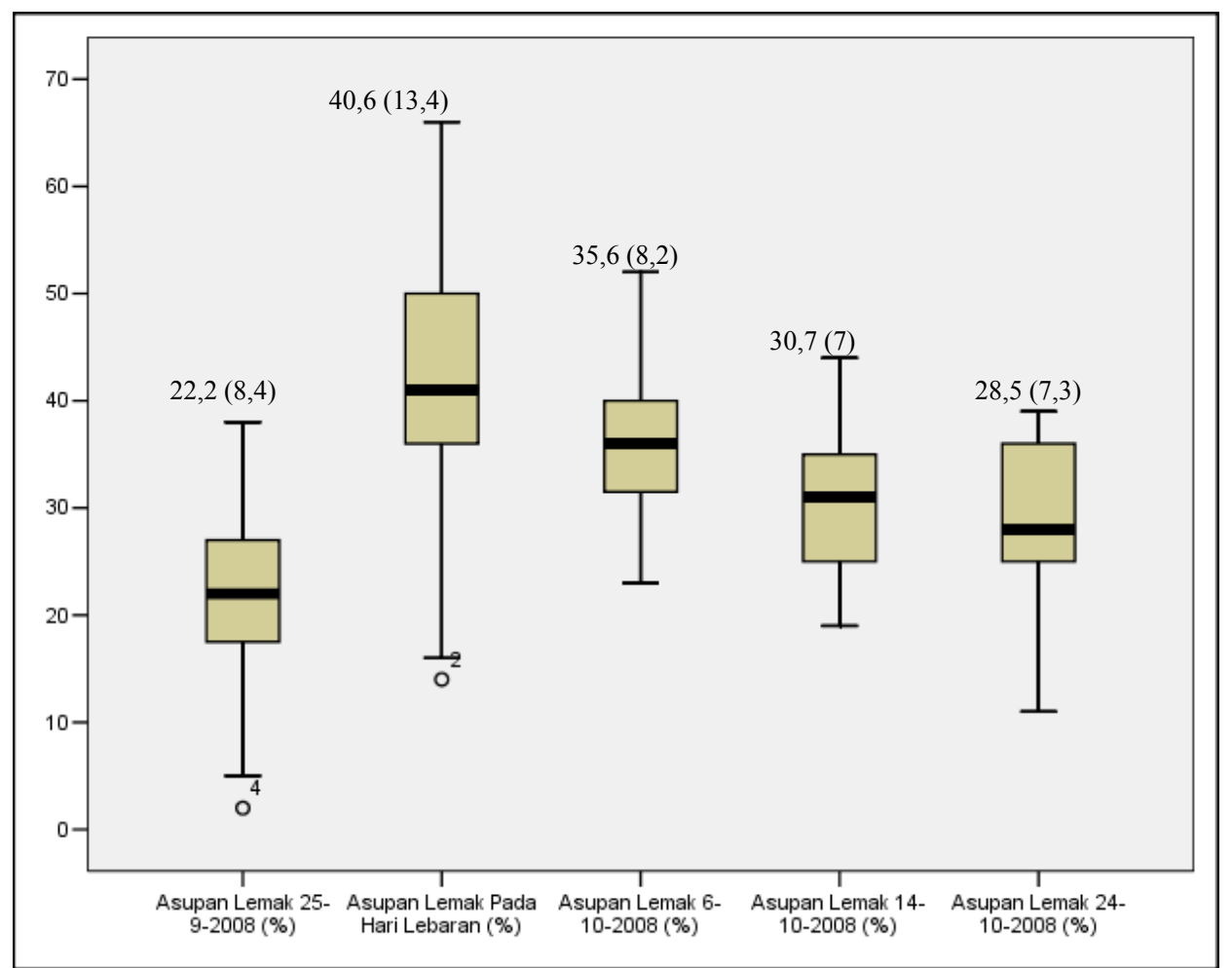

Gambar 4 Asupan Lemak (\%) pada Akhir Puasa Ramadan (25/9/2008), Hari Raya Idul Fitri, 1 minggu (6/10/2008), 2 minggu (14/10/2008), 3 minggu (24/10/2008) setelah Idul Fitri pada Kompi Yonkav 4 Tank

Untuk menilai perbedaan persentase asupan energi yang berasal dari karbohidrat antara akhir puasa Ramadan dengan hari raya Idul Fitri, 1 minggu, 2 minggu, 3 minggu setelah hari raya Idul Fitri, menggunakan uji non parametrik Friedman $(p<0,05)$ dengan kemaknaan $\mathrm{p}=0,000$.

Hasilnya menunjukkan adanya kenaikan asupan energi pada hari raya Idul Fitri, 1 minggu, 2 minggu, 3 minggu setelah hari raya Idul Fitri dibandingkan dengan akhir puasa Ramadan (gambar 1 dan tabel 2). Asupan energi yang berasal dari karbohidrat lebih sedikit pada hari raya Idul Fitri, 1 minggu, 2 minggu, 3 minggu setelah hari raya Idul Fitri dibandingkan dengan akhir puasa Ramadan (gambar 2 dan tabel 3).

Sedangkan asupan energi yang berasal protein tidak ada perubahan yang bermakna (Gambar 3). Sebaliknya dari asupan energi yang berasal dari karbohidrat, asupan energi yang berasal dari lemak pada hari raya Idul Fitri, 1 minggu, 2 minggu, 3 minggu setelah hari raya Idul Fitri lebih besar dibandingkan dengan akhir puasa Ramadan (Gambar 4 dan tabel 4).

Untuk menilai perbedaan persentase asupan energi yang berasal dari protein antara akhir puasa Ramadan dengan hari raya Idul Fitri, 1 minggu, 2 minggu, 3 minggu setelah hari raya Idul Fitri, menggunakan uji non parametrik Friedman dengan kemaknaan $\mathrm{p}=0,06$.

Untuk menilai perbedaan asupan protein (\%) antara akhir puasa Ramadan dengan 1 minggu, 2 minggu, 3 minggu setelah hari raya Idul Fitri, menggunakan uji non parametrik Friedman dengan kemaknaan $\mathrm{p}=0,000$.

\section{DISKUSI}

Dari hasil penelitian, ditemukan kenaikan asupan energi total (kkal) pada hari raya Idul Fitri, 1 minggu, 2 minggu, 3 minggu setelah hari raya Idul Fitri dibandingkan dengan akhir puasa Ramadan pada kompi Yonkav 4 Tank berdasarkan uji Friedman $(p<0,05)$ dan uji Wilcoxon $(p<0,05)$. Peningkatan asupan energi terutama berasal dari asupan lemak. Hal ini dibuktikan oleh uji Friedman $(p<0,05)$ dan uji Wilcoxon $(p<0,05)$ yang menunjukan adanya peningkatan asupan lemak (\%) pada 1 minggu, 2 minggu, 3 minggu setelah hari raya Idul Fitri dibandingkan dengan akhir puasa Ramadan. Sedangkan asupan karbohidat (\%) pada 1 minggu, 2 minggu, 3 minggu setelah hari raya Idul Fitri menunjukan adanya penurunan bila dibandingkan dengan pada akhir puasa Ramadan. 
Asupan protein (\%) setelah hari raya Idul Fitri pada kompi Yonkav 4 Tank tidak ada perubahan.

Terjadinya peningkatan asupan makanan yaitu peningkatan asupan energi total dan asupan lemak (\%) pada hari raya Idul Fitri, 1 minggu, 2 minggu, 3 minggu setelah hari raya Idul Fitri dibandingkan dengan akhir puasa Ramadan pada kompi Yonkav 4 Tank oleh karena pada saat hari raya Idul Fitri terdapat makanan yang berlimpah sehingga seseorang cenderung untuk makan banyak. Hal ini sejalan dengan pernyataan Berthoud yang menemukan bahwa meskipun tubuh kita mempunyai sistem yang dapat menjaga keseimbangan antara pemenuhan kebutuhan energi dengan penimbunan lemak, namun faktor lingkungan dapat menyebabkan perubahan dalam sistem tubuh (Berthoud, 2004). Menurut Oumesh dan Bayat, salah satu contoh faktor lingkungan yang dapat mempengaruhi sistem tubuh dalam menjaga keseimbangan antara pemenuhan kebutuhan energi dengan penimbunan lemak adalah saat hari raya Idul
Fitri (Oumeish, 1997; Bayat 2007). Pada saat hari raya Idul Fitri terdapat makanan yang melimpah dan tradisi mengunjungi kerabat. Hal inilah yang mendorong terjadinya asupan makanan yang meningkat pada saat hari raya Idul Fitri.

Selain itu kebiasaan makan selama bulan puasa yang cenderung tinggi karbohidrat setelah Hari Raya Idul Fitri bergeser menjadi cenderung tinggi lemak. Hal ini berbeda dengan hasil penelitian Al-Hourani yang mendapatkan bahwa kecenderungan mengkonsumsi makanan tinggi karbohidrat, protein dan lemak akan dipertahankan hingga hari raya Idul Fitri (Al-Hourani dan Atoum, 2007). Hal ini terjadi karena pada saat puasa Ramadan di Indonesia terjadi kecenderungan untuk mengkonsumsi makanan manis saat berbuka puasa, seperti kolak pisang. Akan tetapi, pada saat hari raya Idul Fitri terdapat kecenderungan untuk mengkonsumsi makanan yang tinggi lemak, seperti gulai dan opor.

\section{DAFTAR PUSTAKA}

1. Al-Hourani, H.M. and M.F. Atoum. 2007. Body composition, nutrient intake and physical activity patterns in young women during Ramadan. Singapore Med J, 2007. 48(10): p. 906-910.

2. Bayat, A.. 2007. Islamism and the Politics of Fun. Public Culture. 19(3): p. 433-459.

3. Beltaifa, L., et al. 2002. Food intake, and anthropometrical and biological parameters in adult Tunisians during fasting at Ramadan. East Mediterr Health J, 2002. 8(4-5): p. 603-611.

4. Berthoud, H.R.. 2004. Mind versus metabolism in the control of food intake and energy balance. Physiology \& Behavior. 81: p. 781-793.

5. Dulloo, A.G. and L. Girardier. 1993. Adaptive role of energy expenditure in modulating body fat and protein deposition during catch-up growth after early undernutrition. Am J Clin Nutr. 58(5): p. 614-621.

6. Dulloo, A.G., et al. 1995. Differential effects of highfat diets varying in fatty acid composition on the efficiency of lean and fat tissue deposition during weight recovery after low food intake. Metabolism. 44(2): p. 273-279.

7. Dulloo, A.G., J. Jacquet, and L. Girardier. 1996. Autoregulation of body composition during weight recovery in human: the Minnesota Experiment revisited. Int J Obes Relat Metab Disord. 20(5): p. 393-405.
8. Dulloo, A.G., J. Jacquet, and J.P. Montani. 2002. Pathways from weight fluctuations to metabolic diseases: focus on maladaptive thermogenesis during catch-up fat. Int $J$ Obes Relat Metab Disord. 26 Suppl 2: p. S46-S57.

9. Hoffer, L.J. 2006. Metabolic Consequences of Starvation. $10 \mathrm{Ed}$. Modern Nutrition in Health and Disease, ed. M.E. Shils, et al., Philadelphia: Lippincott.

10. Hall, K.D. 2006. Computational model of in vivo human energy metabolism during semistarvation and refeeding. Am J Physiol Endocrinol Metab. 291(1): p. E23-E37.

11. Gharbi, M., M. Akrout, and B. Zouari. 2003. Food intake during and outside Ramadan.East Mediterr Health J, 2003. 9(1-2): p. 131-140.

12. Kurpad, A.V. 2005. Undernutrition. Clinical Nutrition, ed. M.J. Gibney, et al.: Blackwell Science.

13. Lamine, F., et al. 2006. Food intake and high density lipoprotein cholesterol levels changes during ramadan fasting in healthy young subjects. Tunis Med. 84(10): p. 647-650.

14. Oumeish, O.Y. 1998. The Philosophical, Cultural, and Historical Aspects of Complementary, Alternative, Unconventional, and Integrative Medicine in the Old World. Arch Dermatol. 134(11): p. 1373-1386. 